Review article

\title{
A mini-review on the pharmacognosy and phytochemistry of a tropical medicinal plant: Annona senegalensis Pers. (Annonaceae)
}

\author{
Koto-te-Nyiwa Ngbolua ${ }^{1,2,3 *}$, Emmanuel Lengbiye Moke', John Likolo Baya ${ }^{2,4}$, \\ Ruphin Djolu Djoza ${ }^{2}$, Colette Masengo Ashande ${ }^{2}$ and Pius T. Mpiana ${ }^{5}$ \\ ${ }^{1}$ Département de Biologie, Faculté des Sciences, Université de Kinshasa, B.P. 190 Kinshasa XI, \\ République Démocratique du Congo \\ ${ }^{2}$ Département des Sciences de l'Environnement, Faculté des Sciences, Université de Gbadolite, B.P. 111 \\ Gbadolite, Province du Nord Ubangi, République Démocratique du Congo \\ ${ }^{3}$ Institut Supérieur Pédagogique d'Abumombazi, Province du Nord Ubangi, République \\ Démocratique du Congo \\ ${ }^{4}$ Université de Lisala, Province de la Mongala, République Démocratique du Congo \\ ${ }^{5}$ Département de Chimie, Faculté des Sciences, Université de Kinshasa, B.P. 190 Kinshasa XI, \\ République Démocratique du Congo
}

*Corresponding Author: jpngbolua@unikin.ac.cd

[Accepted: 15 April 2017]

\begin{abstract}
The aim of this mini-review was to collect data obtained from various studies carried out by different authors concerning the phytochemistry and pharmacognosy of Annona senegalensis (Annonaceae). This review has been compiled using references from major databases such as PubMed, PubMed Central, Science Direct and Google scholars. An extensive survey of literature revealed that $A$. senegalensis is a good source of health promoting secondary metabolites such as terpenoic acids (kaurenoic acid) among others that could have many wonderful applications (like antisickling properties).Traditionally, the plant is used as stimulant, pain reliever etc. whereas the plant possess beneficial effects such as anti-oxidant, antimicrobial, Antidiarrheal, anti-inflamatory, anti-parasitic, anticonvulsant, antimalarial, anti-trypanosomal, antisnake venom and Antinociceptive and many other medicinal properties. The results of the present review of literature makes A. senegalensis an interesting candidate for advanced anti-sickle cell anemia investigations such as erythroid differentiation and fetal hemoglobin induction effects of this plant using K562 cell lines as model system.
\end{abstract}

Keywords: Traditional Medicine - Annona senegalensis - Phytochemicals - Scientific validation Biodiversity valorization.

[Cite as: Ngbolua KN, Moke EL, Baya JL, Djoza R, Ashande CM \& Mpiana PT (2017) A mini-review on the pharmacognosy and phytochemistry of a tropical medicinal plant: Annona senegalensis Pers. (Annonaceae). Tropical Plant Research 4(1): 168-175]

\section{INTRODUCTION}

As per the records of World Health Organization, it is assumed that more than $60 \%$ of global population is using the traditional medicine system to overcome several health related issues (Farnsworth 1994, Cotton 1997). This percentage goes up in the developing countries where, rural and tribal population is higher because of its low cost (Mehra et al. 2014, Bajpai et al. 2016). Recent findings revealed that over $80 \%$ of the African population relies on medicinal plant species for their primary healthcare (Ngbolua et al. 2011a, b).

In the case of Sickle cell disease (SCD) treatment based plants, Bianchi et al. (2009) reported that phytochemicals (like resveratrol) are able to ameliorate the state of SCD patients by shifting from monthly blood transfusion dependency to a stable transfusion-free condition. The correlation between in vitro effects of such fetal hemoglobin $(\mathrm{HbF})$ inducers and in vivo treatment is well established. The complementary and alternative medicine constitutes therefore a solution for the management of this hemoglobinopathy. Thus, the 
search and the development of antisickling herbal drugs are a priority agenda in Africa, where SCD is endemic. In such region, herbal medicines are widely used to relieve the symptoms of SCD. In our efforts to search for novel and bioactive antisickling hits from indigenous plants, we recently investigated plant species indigenous to Democratic Republic of the Congo which are prescribed by traditional healers or sold in the markets for the management SCD (Ngbolua et al. 2014a, Ngbolua et al. 2016). Annona senegalensis Pers. is one of the plants traditionally used for this purpose. The aim of the present review is to document research results on the pharmacognosy and phytochemistry of this promising medicine. These findings are highlighted in this mini review. Such informations should pave the way for future directional research on this plant species as valuable source of new hits against Sikle cell anemia (epigenetic modulator agents) and associated pathogenic bacteria (antibacterial agents).

\section{BOTANY AND DESCRIPTION}

Annona senegalensis Pers. is a tropical plant species also known as 'wild custard apple' or 'wild soursop'. It is a shrub $(2-6 \mathrm{~m})$ or small tree $(11 \mathrm{~m})$ under some suitable ecological conditions. The bark is smooth to roughish, silver grey or grey-brown. The leaves of this medicinal plant are alternate, simple, oblong, ovate or elliptic, green to bluish green, mostly lacks hairs on upper surface, with brownish hairs on lower surface. Flowers are up to $3 \mathrm{~cm}$ in diameter on stalks $2 \mathrm{~cm}$ long, solitary or in groups of 2-4, arising above the leaf axils. The fruits are formed from many fused carpels, fleshy, lumpy, egg shaped, $2.5-5.0$ by $2.5-4.0 \mathrm{~cm}$, ovoid or globose, unripe fruit green, turning yellow to orange on ripening. Wild fruit trees of this species are found in semi-arid to sub-humid regions of Africa, it is native to tropical east and northeast, west and west- central, and southern Africa, as well as southern subtropical Africa, and islands in the western Indian Ocean. The species occur along river banks, fallow land, swamp, forests and at the coast. It commonly grows as a single plant in the understorey of savannah woodlands (Orwa et al. 2009).

\section{ETHNOBOTANY}

Annona senegalensis Pers. (Annonaceae) is a multipurpose plant with a high traditional and medicinal uses for the maintenance of free health life. Traditionally the plant is used as stimulant, pain reliever etc. Several uses of the plant species is reported for example anti-oxidant, antimicrobial, antidiarrheal, antiinflammatory, antiparasitic, anticonvulsant, antimalarial, antitrypanosonal, anti-snake venom and antinociceptive properties and many other biomedical properties of pharmaceutical relevance. These properties of the plant possess is due to its important phytochemical constituents like triterpenes, anthocyanes, glucids, coumarins, flavonoids and alkaloids etc. (Samuel et al. 2016).

As per the traditional medicine practices, all the plant parts of A. senegalensis are useful in several diseases. The leaves have been used in treating yellow fever, tuberculosis, and small pox (Ajaiyeoba et al. 2006, Mustapha et al. 2013). The stem bark has been used in snakebite and hernia treatment (Dambatta \& Aliyu 2011). The root is used in conditions such as difficulty in swallowing, gastritis, snake bites, male sexual impotence, erectile dysfunction, tuberculosis, and as antidote for necrotizing toxins; the root bark is effective in infectious diseases (Ofukwu et al. 2008, Jiofack et al. 2009, Noumi \& Safiatou 2015). Juice from the tree is used in the treatment of chicken pox (Faleyimu \& Akinyemi 2010). Many of the plant parts are used as antidotes for venomous bites and in the management of diabetes (Ogoli et al. 2011, Ahombo et al. 2012). In Guinea, A. senegalensis has been employed in the treatment of malaria (Traore et al. 2013). Among the Igede people of Benue State in North Central Nigeria, the plant is used in combination with Ageratum conyzoides for diarrhoea and in combination with Nauclea latifolia for dysentery (Igoli et al. 2005).

\section{PHARMACOGNOSY}

Antidrepanocytary (antisickling) activity

Annona senegalensis Pers.from Democratic Republic of the Congo was reported to possess antidrepanocytary (anti-sickle cell anaemia) activity (Mpiana et al. 2007, Mpiana et al. 2012).

Antidiarrhoeal activity

The methanol stem-bark extract of Annona senegalensis was investigated using both in vivo and in vitro models by oral application of effective dose $\left(5000 \mathrm{mg} \cdot \mathrm{kg}^{-1}\right)$. In order to investigate intestinal transit time, the plant extract was given by oral route to mice fed with charcoal as meal. The extract decreased intestinal transit time by decreasing the spontaneous contractions of the intestine, thus the findings provided a scientific basis for 
the use of Annona senegalensis stem bark extract in the treatment of diarrhoea. Therefore, A. senegalensis is a potent phytomedicine for diarrhoea (Suleiman et al. 2008).

Antimalarial and filarial mosquito vectors activity

The methanol extract of Annona senegalensis possess antimalarial activity against Plasmodium berghei and the extract showed better antimalarial activity than compared to the standard reference drug Chloroquine disphosphate which had a 96.2\% chemosuppression activity (Ajaiyeoba et al. 2006). In DRC antimalarial and cytotoxic activities of tested plant extract moderate in vitro (i.e. $10<\mathrm{IC}_{50}<50 \mu \mathrm{g} / \mathrm{mL}$ : A. senegalensis $\mathrm{IC}_{50}=32$, $52 \pm 6,97 \mu \mathrm{g} . \mathrm{ml}^{-1}$ ) and weak in vivo (i.e. $\% \mathrm{I}<33,00 \pm 2: \% \mathrm{I}=16,93 \pm 2,00$ ). The ethanolic crude extract from the leaves of $A$. senegalensis displayed also cytotoxic effect towards P-388 cells $\left(\mathrm{IC}_{50}<10 \mu \mathrm{g} \cdot \mathrm{ml}^{-1}\right.$, therapeutic index $=0,27)$. The observed cytotoxic effect of the leaves could be due to presence of aporphine alkaloid (Ngbolua et al. 2014b). These results are not consistent with previously reported research work. Indeed (Ajaiyeoba et al. 2006) reported that A. senegalensis harvested in Nigeria had intrinsic antimalarial property that was dose- dependent. They found that, at dose of $100 \mathrm{mg} \cdot \mathrm{kg}^{-1}$ body weight of mice, methanolic extract produced significant chemosuppression of parasitemia (> 57\%) when administered orally. It had the highest activity at $800 \mathrm{mg} \cdot \mathrm{kg}^{-1}$ weight of mice $(91.1 \%)$. Their extract exhibited low cytotoxicity against A2780 ovarian cancer cells (with an IC50 of 28, $8 \mu \mathrm{g} \cdot \mathrm{ml}^{-1}$ ). The antimalarial effectiveness of A. senegalensis from DRC has not formerly demonstrated in vivo, it could be a question of a plant which used by traditional healers to alleviate or prevent a wide range of malaria symptoms because of its anti-inflammatory, immunostimulant, antipyretic or vasorelaxant effects or a plant species which potentiates other plants and thus its effectiveness would depend on associations of the plants (Rasoanaivo et al. 2004, Ngbolua et al. 2014b).

Spermatogenic activity

Oladele et al. (2014) tested the aqueous leaf extract of A. senegalensis at different doses of 200, 300, and $500 \mathrm{mg} . \mathrm{kg}^{-1}$ body weight for its spermatogenic effect. Results showed the weight of the testes and epididymis increased significantly for the 300 and $500 \mathrm{mg} \cdot \mathrm{kg}^{-1}$ doses. The sperm concentration for the 200, 300 and 500 $\mathrm{mg} \cdot \mathrm{kg}^{-1}$ doses also significantly increased and the sperm motility at 300 and $500 \mathrm{mg} \cdot \mathrm{kg}^{-1}$ also increased significantly. Decrease in abnormal sperm morphology was not significant for any of the doses. However, another study revealed that aqueous leaf extract of A. senegalensis may possess the potential to adversely affect testicular function in rat (Nwonuma et al. 2015).

\section{Antimicrobial activity}

In a study of methanol-methylene chloride extract of the root bark of A. senegalensis, the ethyl acetate fraction on further fractionation gave two active subfractions, a lipophilic oily and another fraction (AS2) which on purification precipitated white crystalline compound, later characterized to be kaurenoic acid. MICs of the ethyl acetate fraction, the lipophilic oily fraction and kaurenoic acid against Bacillus subtilis were 180, 60, and $30 \mu \mathrm{g} \cdot \mathrm{ml}^{-1}$ respectively. AS2 exhibited activity against Staphylococcus aureus with an MIC of $150 \mu \mathrm{g} \cdot \mathrm{ml}^{-1}$, while the lipophilic oily fraction was active against Pseudomonas aeruginosa with an MIC of $40 \mu \mathrm{g} \cdot \mathrm{ml}^{-1}$. However, the extract and kaurenoic acid exhibited no effects against Candida albicans and Aspergillus niger (Jada et al. 2015).

Ethanol extract of the plant had in vitro antimicrobial activity against some oral pathogens (More et al. 2008). An extract of recipe containing six plants including A. senegalensis had significant antibacterial activity with (MIC) of $62.5 \mu \mathrm{g} \cdot \mathrm{ml}^{-1}$ against Staphylococcus aureus and $250 \mu \mathrm{g} \cdot \mathrm{ml}^{-1}$ against Candida albicans (Aiyeloja \& Bello 2006).

\section{Antioxidant activity}

It is concluded that antioxidant activity and drug detoxification activity of Annona senegalensis leave in carbon tetrachloride-induced hepatocellular damage in rats using 2, 2-diphenyl-1-picrylhydrazyl (DPPH) radical, superoxide ion, hydrogen peroxide $\left(\mathrm{H}_{2} \mathrm{O}_{2}\right), 2,2$-azinobis-(3-ethylbenzthiazoline-6-sulfonate) (ABTS) and ferric ion models decreased significantly. The responsible chemical constituent of antioxidant activity may be due to the presence of flavonoids in the extracts (Ajboye et al. 2010).

\section{Anti-inflammatory activity}

Anti-inflammatory activities of the leaves extract of A. senegalensis were determined in rats in inflammatory models. The extract induced a significant decrease in the number of inflammatory cells. This effect is probably due to higher concentrations of tannins and phenolic compounds in the extract of plant (Yeo et al. 2011). 
Haemostatic activity

A. senegalensis is sold by herbalists in South Benin for treatment of bleeding. Dandjesso et al. (2012), in a bid to find scientific evidence for this use, performed in vitro haemostatic tests on hydro alcoholic extracts of the leaves. Results confirmed its anticoagulant properties, as indicated by a $39 \%$ reduction of plasma recalcification time. A. senegalensis was also shown to have astringent property, so it could act on primary haemostasis through vasoconstriction.

Anticonvulsant activity

Anticonvulsant activities of the root bark extract on pilocarpine-induced seizures in animal model was evaluated. The results proved the efficacy of A. senegalensis in the treatment of epilepsy and convulsions (Konate et al. 2012). Kaurenoic acid (KA) was identified as the anticonvulsant principle in the root bark extract of $A$. senegalensis. The anticonvulsant effect of KA is most likely being mediated through central inhibitory mechanisms.

In vivo trypanocidal activity

The aqueous extract of A. senegalensis possesses trypanocidal activity against Trypanosoma brucei in infected mice (Ogbadoyi et al. 2007).

Anti-snake venom activity

(Adzu et al. 2005), tested the power of the methanol extract of the root bark of the Annona senegalensis was tested on brine shrimp (Artemia saline Leach) against cobra (Naja nigricotlis nigricolis Wetch) venom in rats. They further reported that the reduction in the induced hyperthermia directly detoxified the snake venom used by $16-33 \%$. However, the extract doesn't restore the liver functions.

Antinociceptive activity

The methanolic extract of Annona senegalensis was reported to display antinociceptive property in a various test models. The analgesic effect of the methanolic this plant extract might be through peripheral mechanisms. This pharmacological property justifies the use of the plant species in traditional medicine to treat rheumatic pain (Adzu et al. 2003).

Anthelmintic activity

Alawa et al. (2003) investigated the efficacy of the extract of Annona senegalensis against Haemonchus contortus eggs and was shown a significant reduction in the egg hatch and larval recovery as the concentration increases.

Hypnotic activity

Effect of extract and fractions of A. senegalensis leaves on pentobarbitone-induced sleeping time was assessed. The extract and fractions significantly $(\mathrm{p}<0.05)$ shortened the sleep onset time (sleep latency) and prolonged sleeping time in a dose-related manner. A bioactive fraction significantly $(\mathrm{P}<0.05)$ prolonged sleep time but increased sleep latency in a dose-related manner (Okoli et al. 2010). Extracts of the root bark also potentiated the central nervous system depressant effect of phenobarbitone in a dose dependent fashion (Otimenyin \& Omeri 2014).

\section{PHYTOCHEMISTRY}

Phytochemical screening of Annona senegalensis revealed the presence of various secondary metabolites including tannins (Jada et al. 2014), flavonoid (Jada et al. 2015), saponins (Afolabi \& Afolabi 2013), alkaloids (You et al. 1995), glycosides, steroids (Ijaiya et al. 2014), volatile oil (Ngamo et al. 2007), anthocyanins (Mpiana et al. 2012), triterpenes and coumarins. GC/MS study of stem bark of A. senegalensis showed the presence of 1, 2 benzenediol, butylated hydroxytoluene (BHT), Phenol, 2, 6 bis (1, 1-dimethylethyl-4methyl, methylcarbamate, $\mathrm{n}$ hexadecanoic acid, hexadecane, 13- hexyloxacyclotridec-10-en-2one, oleic acid, tetracosane, 9- octylheptadecane, heneicosane, 12-mehtyl-E, E-2, 13- octadecadien-1-ol, octadecanoic acid, 9, 17-octadecandienal, pentadecane, tetratriacontane and squalene (Awa et al. 2012). Biochemist in Ahmadu Bello University, Zaria, Nigeria has been reported that a hydroxylated phenol which is 2-benzenediol or catechol is toxic to microorganisms (Awa et al. 2012).

The diterpenoid, kaur-16-en-19-oic acid or kaurenoic acid was reported as phytochemical constituent responsible for the antibacterial effects of root bark (Okoye et al. 2012). A. senegalensis has also been found to contain various minerals such as $\mathrm{Ca}, \mathrm{K}, \mathrm{Mg}, \mathrm{Zn}, \mathrm{Fe}, \mathrm{Cu}, \mathrm{Mn}, \mathrm{Pb}, \mathrm{Cr}$ as well as ascorbic acid and amino acids, making it an important source of nutrients (Yisa et al. 2010).

www.tropicalplantresearch.com 
The GC and GC-MS analyses showed that p-cymene (36.0\%), $\alpha$-phellandrene (25.0\%), $\alpha$-pinene (8.3\%), Zsabinol $(6.9 \%)$ and limonene $(4.8 \%)$ are the major compounds A. senegalensis stem bark essential oil (Khallouki et al. 2002). In another study, the leaf essential oil of A. senegalensis had oxygenated monoterpenes (65.0\%) as the major compounds and contains also citronellal (30.0\%), citronellol (14.8\%), geranial (17.2\%), thymol (8.1\%), $\beta$-caryophyllene (7.8\%) and carvacrol (6.92\%) (Ameen et al. 2011). The GC and GC/MS analyses of the essential oil of A. senegalensis from Burkina Faso displayed the presence of germacrene D (19.2\%), $\beta$-caryophyllene (19.1\%), $\gamma$-cadinene (11.1\%) and $\alpha$-humulene $(9.7 \%)$ as major components (Nébiéa et al. 2002). In Brazzaville (Congo), essential oils were found in all parts of A. senegalensis including leaves, stem bark, root bark, epicarp and mesocarp (Nkounkou et al. 2010).

In Nigeria, nineteen monoterpenes and sesquiterpenes were identified in the essential oils of the leaves and fruits of A. senegalensis. The major constituents were car-3-ene in the fruit oil and linalool in the leaf volatile oil (Ekundayo \& Oguntimein 1986).

Two new cyclopeptides, cyclosenegalin A, cyclo (Pro $\left.{ }^{1}-\mathrm{Gly}^{2}-\mathrm{Leu}^{3}-\mathrm{Ser}^{4}-\mathrm{Ala}^{5}-\mathrm{Val}^{6}-\mathrm{Thr}^{7}-\right) \quad(\mathbf{1})$ and cyclosenegalin B, cyclo ( $\mathrm{Pro}^{1}-\mathrm{Gly}^{2}-\mathrm{Tyr}^{3}-\mathrm{Val}^{4}-\mathrm{Tyr}^{5}-\mathrm{Pro}^{6}-\mathrm{Pro}^{7}-\mathrm{Val}^{8}-$ ) (2), were isolated and structurally characterized from the methanol extract of the seeds of Annona senegalensis Pers., along with the known cyclic peptide, glabrin A. The structures of the isolated compounds were characterized on the basis of the MS/MS fragmentation, using a Q-TOF mass spectrometer equipped with an ESI source, chemical degradation and extensive 2D-NMR (Alassane et al. 2002). Bioactive-guided fractionation of the methanol-methylene chloride root bark extract (MME) of A. senegalensis using pentylenetetrazole (PTZ)-induced seizures in mice, afforded ethyl-acetate fraction (EF) with anticonvulsant activity. The chromatographic fractionation of the EF yielded eight sub-fractions $\left(\mathrm{F}_{1}-\mathrm{F}_{8}\right)$ which were submitted to anticonvulsant screening assay. The white crystals from the sub-fraction F2 were purified to afford A. senegalensis crystals, AS2. The AS2, which exhibited potent anticonvulsant effects, was characterized by 1D and 2D NMR spectroscopy, mass spectroscopy and X-ray crystallography (Okoye et al. 2013). Chromatographic fractionation of the methanol-methylene chloride root bark extract of A. senegalensis afforded a potent antibacterial ethyl acetate soluble fraction (EF) which gave after additional column chromatography, two active sub-fractions F1 and F2. F1 yielded a lipophilic liquid component while $\mathrm{F} 2$ on purification, precipitated a white crystalline compound that was characterized by proton NMR and X-ray crystallography as kaur-16-en-19-oic acid. F1 was analyzed using GC-MS to obtain 6 major constituents: 1- dodecanol, kaur-16-en-18-oic acid, 1-Naphthalenemethanol, 6, 6-dimethyl-bicyclo [3.1.1] hept2-ene-2-ethanol,3,3-dimethyl-2-(3-methylbuta-1,3-dienyl) cyclohexan-1-methanol and 3-hydroxyandrostan-17carboxylic acid (Okoye et al. 2012).

\section{CONCLUSION}

The pharmacological relevance and diversity of compounds reviewed in this manuscript demonstrate that there is much to be discovered in this medicinal plant. As an anti-sickling plant candidate, there is therefore an urgent need to evaluate this plant species for it biological activity and modes of action of derived organic acids extracts which may shelter some epigenetic modulators drugs for the management of SCD in the future.

\section{REFERENCES}

Adzu B, Abubakar MS, Izebe KS, Akumka DD \& Gamaniel KS (2005) Effect of Annona senegalensis root bark extracts on Naja nigricotlis nigricotlis venom in rats. Journal of Ethnopharmacology 96: 507-513.

Adzu B, Amos S, Adamu M \& Gamaniel K (2003) Anti-nociceptive and Anti-inflammatory effects of the methanol extract of Annona senegalensis root bark. Journal of Natural Remedies 3(1): 63-67.

Afolabi F \& Afolabi O (2013) Phytochemical Constituents of Some Medicinal Plants in South West, Nigeria. IOSR Journal of Applied Chemistry 4(1):76-78.

Ahombo G, Ampa R, Diatewa M, Mpati J, Abena A \& Ouamba J (2012) Investigating on related diabetes therapeutic plants used in traditional medicine at Brazzaville. Journal of Medicinal Plants Research 6(44): 5630-5639.

Aiyeloja A \& Bello O (2006) Ethnobotanical Potentials of Common Herbs in Nigeria: A Case Study of Enugu State. Educational Research and Review 1(1): 16-22.

Ajaiyeoba E, Falade M, Ogbole O, Okpako L \& Akinboye D (2006) In vivo antimalarial and cytotoxic properties of Annona senegalensis extract. African Journal of Traditional, Complementary and Alternative Medicines 3(1): 137-141. 
Ajboye T, Yakubu M, Salau A, Oladiji A, Akanji M \& Okogun J (2012) Antioxidant and Drug Detoxification Potential of Aqueous Extract of Annona senegalensis leaves in Carbon Tetrachloride-Induced Hepatocellular Damage. Pharmaceutical Biology 48(12): 136-170.

Alassane W, Yanjun Z, Christelle C, Jean-Paul B, Lionel D, Catherine G, Jean-Louis P, Mamadou B \& Bernard B (2002) Isolation and structure of cyclosenegalins A and B, novel cyclopeptides from the seeds of Annona senegalensis. Journal of the Chemical Society, Perkin Transactions 1: 2712-2718.

Alawa CB, Adamu AM, Gefu JO, Ajanusi OJ, Abdu PA, Chiezey NP, Alawa JN \& Bowman DD (2003) In vitro screening of two Nigerian medicinal plants (Vernonia amygdalina and Annona senegalensis) for anthelmintic activity. Veterinary Parasitology 113(1): 73-81.

Ameen O, Usman L, Oganija F, Hamid A, Muhammed N \& Zubair M (2011) Chemical composition of Leaf Essential Oil of Annona senegalensis Pers. (Annonaceae) growing in North Central Nigeria. International Journal of Biological and Chemical Sciences 5(1): 375-379.

Awa EP, Ibrahim S \& Ameh DA (2012) GC/MS Analysis and antimicrobial activity of Diethyl ether fraction of Methanolic extract from the stem bark of Annona senegalensis pers. International Journal of Pharmaceutical Sciences and Research 3(11): 4213-4218.

Bajpai O, Pandey J \& Chaudhary LB (2016) Ethnomedicinal uses of tree species by Tharu tribes in the Himalayan Terai region of India. Research Journal of Medicinal Plant 10 (1): 19-41.

Bianchi N, Zuccato C, Lampronti I, Borgatti M \& Gambari R (2009) Fetal Hemoglobin Inducers from the Natural World: A Novel Approach for Identification of Drugs for the Treatment of $\beta$-Thalassemia and Sickle-Cell Anemia. Evidence-Based Complementary and Alternative Medicine 6(2): 141-151.

Cotton CM (1997) Ethnobotany, Principles and Applications. Wiley \& Sons, UK.

Dambatta S \& Aliyu B (2011) A Survey of Major Ethno medicinal plants of Kano North, Nigeria, their Knowledge and Uses by Traditional Healers. Bayero Journal of Pure and Applied Sciences 4(2): 28-34.

Dandjesso C, Klotoé J, Dougnon T, Sègbo J, Atègbo J \& Gbaguidi F (2012) Phytochemistry and Hemostatic Properties of some Medicinal Plants Sold as Anti- Hemorrhagic in Cotonou Markets (Benin). Indian Journal of Science and Technology 5(8): 3105-3109.

Ekundayo O \& Oguntimein B (1986) Composition of the Essential Oils of Annona senegalensis var. Senegalensis. Planta Medica 52(3): 202-204.

Faleyimu O \& Akinyemi O (2010) Herbal Approaches to the Problem of Erectile Dysfunction in Kaduna State, Nigeria. Egyptian Journal of Biology 12: 103-107.

Farnsworth NR (1994) Ethnopharmacology and Drug Development. In: Prance GT \& Marsh J (eds) Ethnobotany and the Search for New Drugs. Ciba Foundation Symposium 185, John Wiley and Sons, Chichester, pp. 42-59.

Igoli J, Ogaji O, Tor-Anyin T \& Igoli N (2005) Traditional Medicine Practice amongst the Igede People of Nigeria. Part II. African Journal of Traditional, Complementary and Alternative Medicines 2(2): 134-152.

Ijaiya I, Arzika S \& Abdulkadir M (2014) Extraction and Phytochemical Screening of the Root and Leave of Annona senegalesis (Wild Custad Apple). Academic Journal of Interdisciplinary Studies 3(7): 9-15.

Jada M, Usman W \& Adamu Y (2014) In vitro Antimicrobial Effect of Crude Tannins Isolated from the Leaf of Annona senegalensis. International Journal of Biochemistry Research \& Review 4(6): 615-623.

Jada M, Usman W \& Olabisi A (2015) Crude Flavonoids Isolated from the Stem Bark of Annona senegalensis have Antimicrobial Activity. Journal of Advances in Biology \& Biotechnology 2(1): 24-29.

Jiofack T, Fokunang C, Guedje N, Kemeuze V, Fongnzossie E, Nkongmeneck B \& Mapongmetsem P (2009) Ethnobotanical Uses of some Plants of Two Ethnoecological Regions of Cameroon. African Journal of Pharmacy and Pharmacology 3(13): 664-684.

Khallouki F, Younos C, Soulimani R \& Bessière J (2002) Chemical Composition of the Essential Oils of Annona cuneata L. and Annona senegallensis Pers. Stem Barks. Flavour and Fragrance Journal 17(5): 398-400.

Konate A, Sawadogo WR, Dubruc F, Caillard O, Ouedraogo M \& Guissou IP (2012) Phytochemicaland Anticonvulsant Properties of Annona senegalensis Pers. (Annonaceae), Plant Used in Burkina Folk Medicine to Treat Epilepsy and Convulsions. British Journal of Pharmacology and Toxicology 3 (5): 245-250.

Mehra A, Bajpai O \& Joshi H (2014) Diversity, utilization and sacred values of Ethno-medicinal plants of Kumaun Himalaya. Tropical Plant Research 1(3): 80-86. 
More G, Tshikalange T, Lall N, Botha F \& Meyer J (2008) Antimicrobial Activity of Medicinal Plants against Oral Microorganisms. Journal of Ethnopharmacology 119(3): 473-477.

Mpiana PT, Dianzenza EN, Ngbolua KN, Tshibangu DST, Mbala BM, Shetonde OM, Atibu EK, Kakule MK \& Bokota MT (2012) Antisickling properties, thermal and photochemical degradations of anthocyanins extract from Annona senegalensis (Annonaceae). International Journal of Biological and Chemical Sciences 6(5): 2241-2251.

Mpiana PT, Tshibangu DST, Shehonde OM \& Ngbolua KN (2007) In vitro antidrepanocytary activity (antisickle cell anemia) of some Congolese plants. Phytomedicine 14(2-3): 192-195.

Mustapha A, Owuna G \& Uthman I (2013) Plant Remedies Practiced by Keffi People in the Management of Dermatosis. Journal of Medicinal Plants Studies 1(5): 112-118.

Nébiéa R, Yaméogoa R, Bélangerb A \& Sibc F (2002) Chemical Composition of Leaf Essential Oil of Annona senegalensis Pers. from Burkina Faso. Journal of Essential Oil Research 17(3): 331-332.

Ngamo TL, Goudoum A, Ngassoum M, Mapongmetsem LG, Malaisse F \& Hance T (2007) Chronic Toxicity of Essential Oils of 3 Local Aromatic Plants towards Sitophilus zeamais Motsch. (Coleoptera: Curculionidae). African Journal of Agricultural Research 2(4): 164-167.

Ngbolua KN, Mpiana PT, Mudogo V, Ngombe NK, Tshibangu DST, Ekutsu E, Kabena ON, Gbolo BZ \& Muanyishay L (2014a). Ethno-pharmacological survey and Floristical study of some Medicinal Plants traditionally used to treat infectious and parasitic pathologies in the Democratic Republic of Congo. International Journal of Medicinal Plants 106: 454-467.

Ngbolua KN, Mudogo V, Mpiana PT, Tshibangu DST, Tshilanda DD \& Masengo CA (2014b) In vitro and in vivo anti-malarial and cytotoxic activities of ethanolic extracts of Annona senegalensis Pers (Annonaceae) from Democratic Republic of the Congo. Journal of Modern Drug Discovery and Drug Delivery Research 2(2): $1-5$.

Ngbolua KN, Rafatro H, Rakotoarimanana H, Ratsimamanga SU, Mudogo V, Mpiana PT \& Tshibangu DST (2011a) Pharmacological screening of some traditionally-used antimalarial plants from the Democratic Republic of Congo compared to its ecological taxonomic equivalence in Madagascar. International Journal of Biological \& Chemical Sciences 5(5): 1797-1804.

Ngbolua KN, Rakotoarimanana H, Rafatro H, RatsimamangaUS, Mudogo V, Mpiana PT \& Tshibangu DST (2011b) Comparative antimalarial and cytotoxic activities of two Vernonia species: V. amygdalina from the Democratic Republic of Congo and V. cinereasubspvialis endemic to Madagascar. International Journal of Biological \& Chemical Sciences 5(1): 345-353.

Ngbolua KN, Shetonde OM, Mpiana PT, Inkoto LC, Masengo CA, Tshibangu DST, Gbolo BZ, Robijaona B \& Fatiany PR (2016) Ethno-pharmacological survey and Ecological studies of some plants used in traditional medicine in Kinshasa city (Democratic Republic of the Congo). Tropical Plant Research 3(2): 413-427.

Nkounkou LC, Gouollaly T, Mahmout Y, Elouma N, Ouamba J \& Chalchat J (2010) Comparative study of the Chemical Composition of the Essential Oils from Organs of Annona senegalensis Pers. Oulotricha le Thomas subspecies (Annonaceae). African Journal of Biotechnology 9(6): 887-891.

Noumi E \& Safiatou M (2015) Some Investigations on the Traditional Pharmacopoeia about Venomous Bites and Stings from Scorpions, Snakes and Spiders in the Hina Subdivision, Far North, Cameroon. British Journal of Pharmaceutical Research 5(5): 344-358.

Nwonuma C, Irokanulo E, Jolaiya A \& Ore A (2015) Effect of Aqueous Leaf Extract of Annona senegalensis on Selected Testicular Function Indices of Wistar Rats. American Journal of Life Sciences 3(3): 203-212.

Ofukwu R, Ayoola A \& Akwuobu C (2008) Medicinal Plants Used in the Management of Tuberculosis in Humans and Animals by Idoma Tribe of North Central Nigeria. Nigerian Veterinary Journal 29(2): 25-30.

Ogbadoyi EO, Abdulganiy AO, Adama TZ \& Okogun JI (2007) In vivo trypanocidal activity of Annona senegalensis Pers. leaf extract against Trypanosoma brucei brucei. Journal of Ethnopharmacology 112(1): $85-89$.

Ogoli J, Tsenongo S \& Tor-Anyin T (2011) A Survey of Anti- venomous, toxic and other Plants used in some parts of Tivland, Nigeria. International Journal of Medicinal and Aromatic Plants 1(3): 240-244.

Okoli C, Onyeto C, Akpa B, Ezike A, Akah P \& Okoye T (2010) Neuropharmacological evaluation of Annona senegalensis leaves. African Journal of Biotechnology 9(49): 8435-8444.

Okoye TC, Akah PA, Okoli CO, Ezike AC, Omeje EO \& Odoh UE (2012) Antimicrobial Effects of a Lipophilic Fraction and Kaurenoic Acid Isolated from the Root Bark Extracts of Annona senegalensis. Evidence-Based 
Complementary and Alternative Medicine 2012: Article ID 831327.

Okoye TC, Peter AA, Edwin OO, Festus BC, Okoye \& Chukwuemeka SN (2013) Anticonvulsant effect of kaurenoic acid isolated from the root bark of Annona senegalensis. Pharmacology Biochemistry and Behavior 109: 38-43.

Oladele G, Faramade I \& Ogunbodede M (2014) Effect of Aqueous Extract of Annona senegalensis leaves on the Spermiogram of Male Albino Rats. World Journal of Pharmaceutical Sciences 3(8): 409-418.

Orwa C, Mutua A, Kindt R, Jamnadass R \& Anthony S (2009) Agroforestree Database: A Tree Reference and Selection Guide Version 4.0.

Otimenyin S \& Omeri F (2014) Hypnotic Effect of Methanolic Extracts of Annona senegalensis Bark and Ficus thonningii leaves in Mice and Chicks. International Journal of Pharmacy and Pharmaceutical Research Human 1(1): 1-12.

Rasoanaivo P, Ramanitrahasimbola D, Rafatro H, Rakotondramanana D, Robijaona B, Rakotozafy A, Ratsimamanga US, Mehdi L, Grellier P, Lucile A, Lengo M \& Frappier P (2004) Screening extracts of Madagascan Plants in search of antiplasmodial compounds. Phytotherapy Research 18: 742-747.

Samuel EO, Edifofon A, Omolola TF, Kevwe BE \& Oluyemisi FK (2016) Annona senegalensis Persoon (Annonaceae): A review of its ethnomedicinal uses, biological activities and phytocompounds. Journal of Pharmacognosy and Phytochemistry 5(2): 211-219.

Suleiman MM, Dzenda T \& Sani CA (2008) Antidiarrhoeal activity of the methanol stem-bark extract of Annona senegalensis pers. (Annonaceae). Journal of Ethnopharmacology 116(1): 125-130.

Traore MS, Baldé MA, Diallo MS, Baldé ES, Diané S \& Camara A (2013) Ethnobotanical survey on medicinal plants used by Guinean traditional healers in the treatment of malaria. Journal of Ethnopharmacology 150(3): 1145-1153.

Yeo D , Dinica R , Yapi HF , Furdui B, Praisler M , Djaman AJ \& N'Guessan JD (2011) Evaluation of the antiinflammatory activity and phytochemical screening of Annona senegalensis leaves. Thérapie 66(1): 73-80.

Yisa J, Egila J \& Darlinton A (2010) Chemical composition of Annona senegalensis from Nupe land, Nigeria. African Journal of Biotechnology 9(26): 4106-4109.

You M, Wickramaratne D, Silva G, Chai H, Chagwedera T \& Farnsworth N (1995) (-)-Roemerine, an Aporphine Alkaloid from Annona senegalensis that Reverses the Multidrug-Resistance Phenotype with Cultured Cells. Journal of Natural Products 58(4): 598-604. 